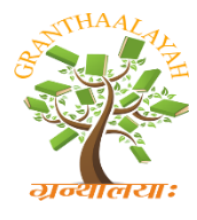

\author{
INTERNATIONAL JOURNAL OF RESEARCH - \\ GRANTHAALAYAH \\ A knowledge Repository
}

Social

\title{
POTENTIALITIES AND CHALLENGES OF ESTABLISHING WATER COURSES BETWEEN RIVERS IN NORTH SUDAN
}

\author{
Gar Al-nabi Ibrahim Mohamed *1 \\ ${ }^{* 1}$ Hydrographic Surveying Department, Faculty of Maritime Studies, King Abdulaziz \\ University, kau
}

\begin{abstract}
The establishment of water courses between the rivers in the study area would reduce Sudan Nile water share surplus and water can be used for pumping and flood irrigation agriculture. This will improve local people standard of living and provide good chances for more people to settle in the area. Excellent contribution to desertification combating can be made as well as a reduction in negative environmental impacts by the increase of the green areas. The effort made in this paper investigated the potentialities and challenges of creating water courses between rivers in north Sudan area. The topographical and hydrological models of the study area were created using its free of charge SRTM90 digital elevation model and QGIS and GRASS application programs. Two water courses were proposed in the area and their geometrical characteristics were discussed. Water course 1 starts from the White Nile river in the White Nile state and ends at the river Nile meandering leg in the northern state with a total length of $415.454 \mathrm{~km}$. Water course 2, starts from the Nile river in the Nile state and ends at the Nile river in the northern state, with a total length of $327.285 \mathrm{~km}$. The investigation revealed the potentialities and highlighted the challenges of creating water courses between rivers in the area. It demonstrated the important role of the open data and application programs in improving local people standards of living, providing chances for more people to settle in and combating the desertification in the area.
\end{abstract}

Keywords: Water Dividing Zone; Valleys Zone; High Lands Zone; Nile Zone; White Nile Zone; Topographical Model; Hydrological Model.

Cite This Article: Gar Al-nabi Ibrahim Mohamed. (2019). "POTENTIALITIES AND CHALLENGES OF ESTABLISHING WATER COURSES BETWEEN RIVERS IN NORTH SUDAN." International Journal of Research - Granthaalayah, 7(1), 88-95. https://doi.org/10.29121/granthaalayah.v7.i1.2019.1038.

\section{Introduction}

The river Nile course, Sudan in Abu Hamed area is characterized by a very long meandering section that approximately, starts from latitude $15^{\circ} \mathrm{N}$, passing latitude $19.5^{\circ} \mathrm{N}$ and coming back to latitude $18^{\circ} \mathrm{N}$, with a meandering longitude span of $1.5^{\circ}$ (158 km approximately), (Fig. 1). Water courses joining the legs of this meandering section will no doubt provide excellent chances 
of living for people in the area, as they are accustomed to making their living along the banks of water courses such as the Nile river and the White Nile river.

This investigation addressed the potentialities and challenges of creating such water courses in the area, using the open data and application programs sources. The topographical model of the area was formed using its free of charge SRTM90 digital elevation model, QGIS and GRASS application programs. This topographical model of the area was used to categorize the area into different topographical zones to facilitate the further analysis stages and limit the investigation effort to the potential parts of the study area.

The hydrological model of the area covering the topographical zones was created and potential water courses in the area were generated by its integration with the topographical model and the topographical zones in the area. The challenges as well as the benefits of creating these water courses were highlighted.

\section{Research Objectives}

The main objective of this research is to investigate the potentialities and challenges of conveying the water from the Sudan White Nile and river Nile to the areas located in the west side of their downstream directions, using open data and application programs sources. In other words, to create water courses in the meandering river Nile between the Khartoum and White Nile states and the northern states, Sudan. This is summarized in figure 1, which shows the general location of the study area, the states, the Nile, White Nile and the expected locations of the water courses.

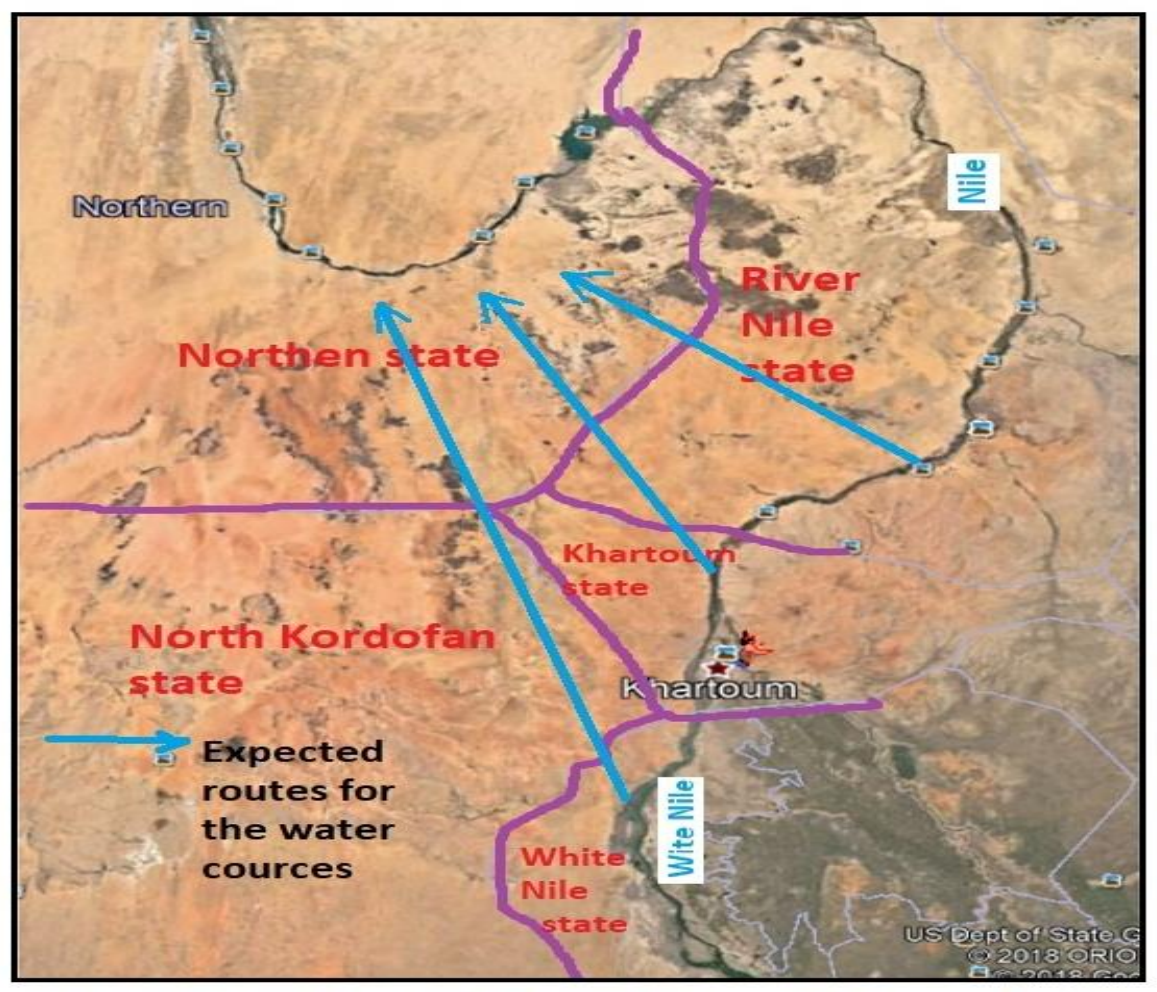

Figure 1, The study area, with its main features and the expected water courses routes. 


\section{Methodology}

The methodology adopted in this investigation may be summarized by the following:

- The SRTM 90 digital elevation model of the area [1] was downloaded and used to generate its topographical and hydrological models and their derivatives, using QGIS [2] and GRASS [3] free of charge application programs.

- The topographical model of the area was used to explore its topographical characteristics and categorize the area into topographical zones for the purpose of the investigation.

- The topographical model, the hydrological model and the topographical zones of the area were integrated to generate the possible water courses between the rivers in the area.

- The geometrical characteristics of the proposed water courses were derived and their challenges were highlighted.

- The study area is located in Kordofan, White Nile, Khartoum, river Nile and northern states in the Sudan. It is bounded by latitudes $13^{\circ}$ and $20^{\circ}$ North and longitudes $30^{\circ}$ and $35^{\circ}$ East. It is an agro-pastoralist area, where livestock and crop production are practiced, along the river's banks. Fig. 2, shows the topographical model of the study area. It demonstrated that contour line $425 \mathrm{~m}$ (red) is dividing the area into five different topographical zones. These zones may be briefly described as follows:

- The high land zone, located in the west side of the area and bounded by contour $425 \mathrm{~m}$ in the east and north sides, the study area boundary in the west side and the White Nile zone in the south side. The elevations in the zone range between 425-1020 m above mean sea level and it is characterized by sand dunes and scattered rock mountains.

- The valleys zone, located in the middle west side of the area and bounded by contour 425 $\mathrm{m}$ in the east, west and south sides and the river Nile in the north side. The elevations in the zone range between 254 and $425 \mathrm{~m}$ above mean sea level, with a general slope in the north west direction. It is characterized by a dense drainage network, fertile valleys and dense trees and bushes along the banks of the water courses.

- The water- divide zone, is located in the middle east side of the area, bounded by the high land zone in the west side and contour $425 \mathrm{~m}$ in the other sides. This zone historically known as Gos Abu Dlooa, and as the name suggests it is mainly characterized by sand dunes and scattered rock out crops. The elevations in this zone range between 425 and 500 $\mathrm{m}$ above mean sea level.

- The Nile zone, is located in the east side of the area, bounded by the river Nile in the north and east sides, contour $425 \mathrm{~m}$ in the west side and the White Nile zone in the south side. It is mainly characterized by scattered drainage network running in the south east direction and a fertile lands zone along the banks of the river. The elevations in this zone range between 325 and $425 \mathrm{~m}$ above mean sea level.

- The White Nile zone is located in the bottom right of the study area, bounded by contour $425 \mathrm{~m}$ in the west side, the White Nile in the east side, Nile zone in the north side and the boundary of the study area in the south side. The elevations in this zone range between 375 and $425 \mathrm{~m}$ above mean sea level. 


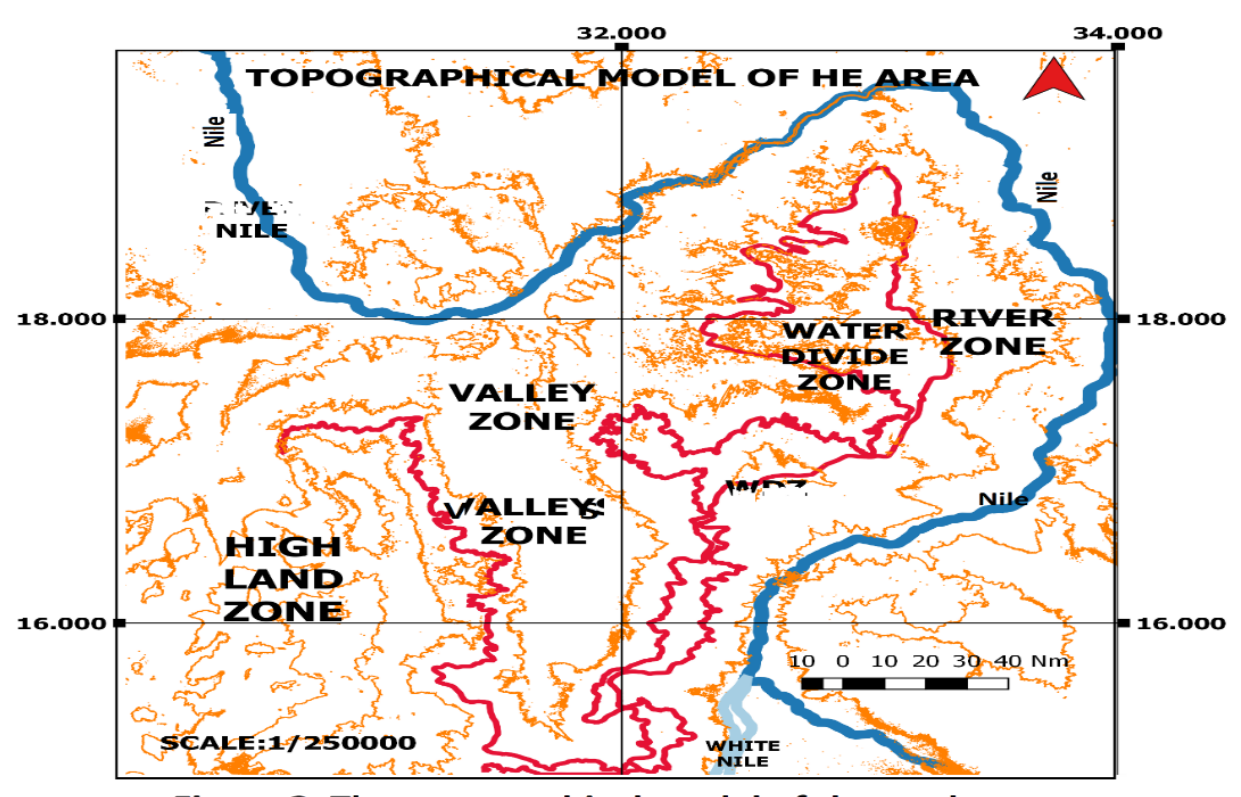

Figure 2, The topographical model of the study area.

\section{Data Processing}

In order to increase the resolution of the data display and final maps and optimize the effort to be made in the investigation, the data processing, analysis and presentation would be confined to the most potential area containing the categorized topographical zones. The topographical and hydrological models of this potential area are presented in Figure 3 and Figure 4 respectively.

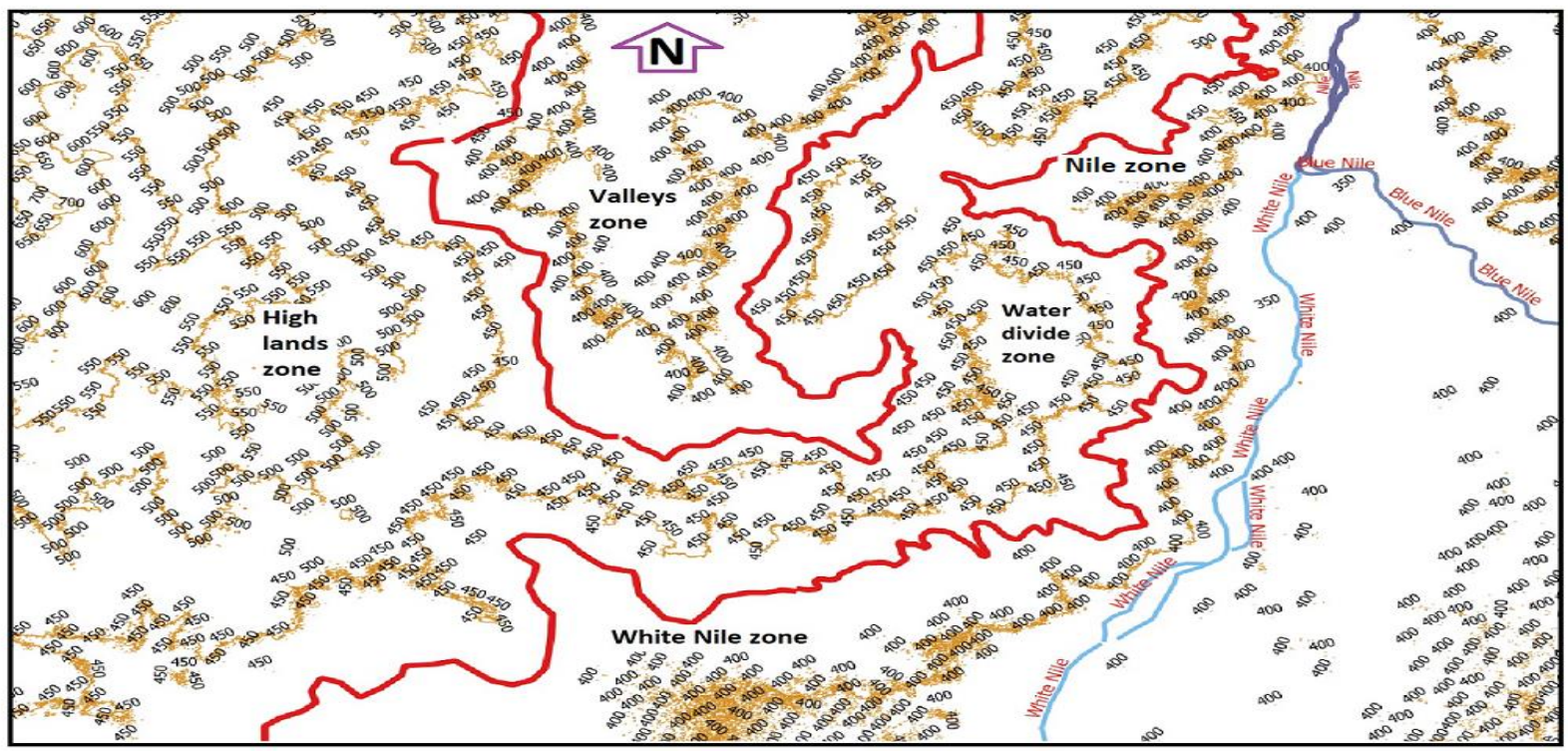

Figure 3, The topographical model of the potential area, with contour $425 \mathrm{~m}$ (red) and topographical zones.

The spatial relationship between the different topographical zones in the potential area is clear in this topographical model (Fig. 3). It is clearly revealed that contour line $425 \mathrm{~m}$ separates the different zones and dictates their general slope directions. However, a better elaboration of this 
spatial relationship can be made in the hydrological model (Fig. 4) and it is characterized by the following:

- The water divide zone drains in two different directions, the south east direction inside both the Nile and the White Nile zones and the north west direction inside the valleys zone.

- The high land zone drains in the south east direction inside both the valleys zone and the White Nile zone.

- The valleys zone drains in the north direction towards the north-east to south-west meandering leg of the Nile.

- The water could easily flow from south to north in the valleys zone by natural gravity.

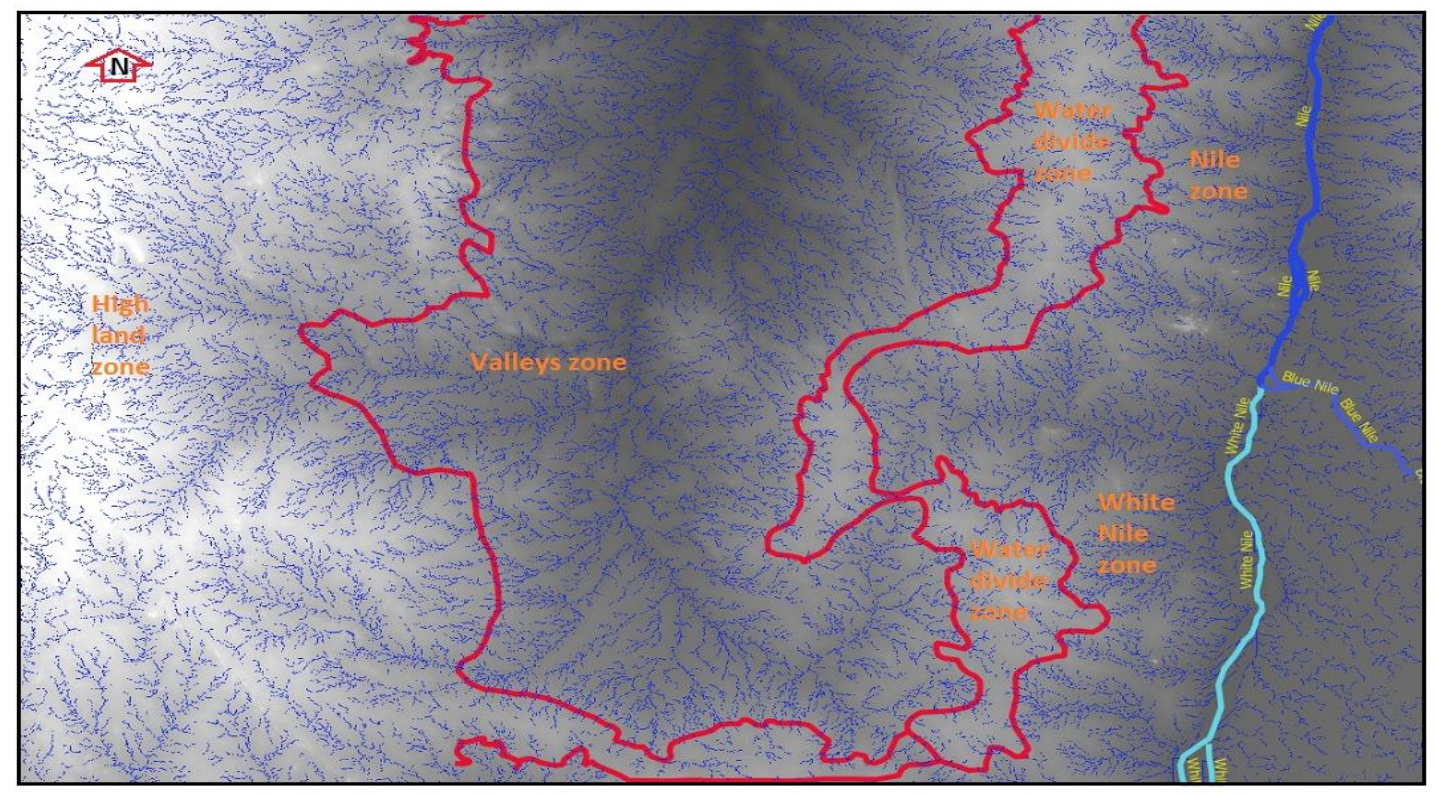

Figure 4, The hydrological model of the potential area, with contour $425 \mathrm{~m}$ (red) and topographical zones.

\section{Results}

It is very clear from the spatial distribution of the topographical zones in the potential area that, crossing the water divide zone is unavoidable for conveying water from the White Nile/Nile through the valleys zone (Fig. 3). Accordingly, the most important parameters to consider for this are:

- The up-stream overhead and distance from the Nile/White Nile to the water divide zone.

- The water divide zone crossing distance and overhead. and

- The length of the natural drainage water course in the valleys zone.

A considerable effort was made by the author in exploring the topographical model, the hydrological model and their integration model using the zoom in /zoom out facility available in the adopted application programs. Two water courses were proposed for conveying water from the White Nile/Nile through the valleys zone (Fig. 6). Water course 1 starts from the White Nile at location (14.726 N, 32.145 E), vicinity of Wad Alsafori village at the west bank of the White Nile. Water course 2 starts at location (16.547 N,32.989 E), vicinity of Algabrab village at the west bank of the river Nile. The geometric data related to the two water courses are presented in table 1. 


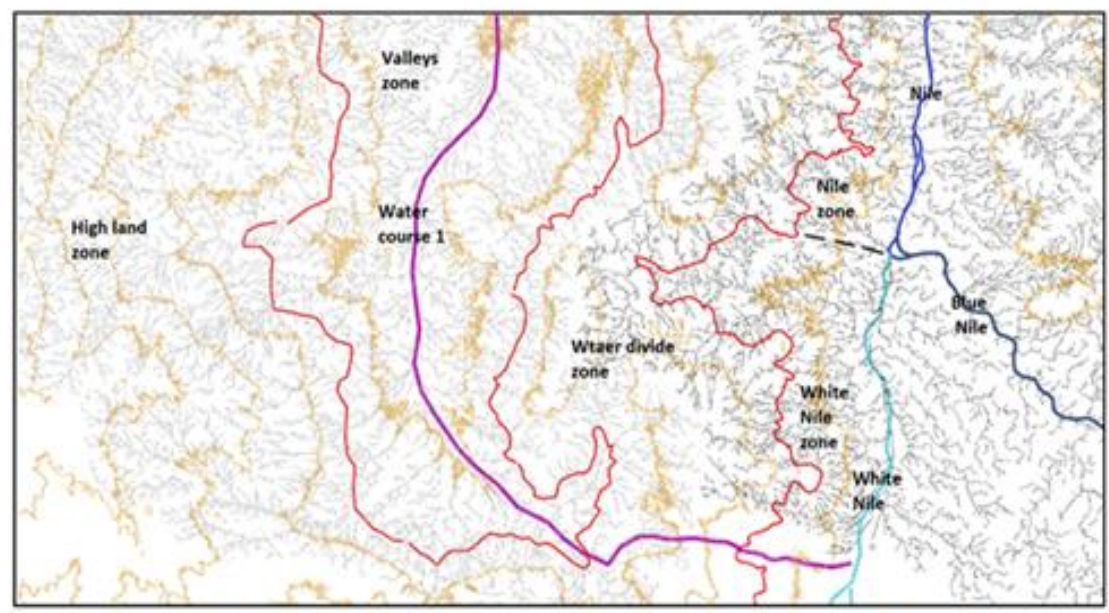

Figure 5, Part of the integration model, showing the topographical and hydrological models, water course 1 and topographical zones in the potential area.

Table 1: Geometric data of the two proposed water courses.

\begin{tabular}{|l|l|l|l|l|l|}
\hline $\begin{array}{l}\text { Water } \\
\text { course }\end{array}$ & $\begin{array}{l}\text { River zone } \\
\text { section }(\mathbf{k m})\end{array}$ & $\begin{array}{l}\text { Water divide zone } \\
\text { section }(\mathbf{k m})\end{array}$ & $\begin{array}{l}\text { Valleys } \\
\text { zone } \\
\text { section } \\
\mathbf{( k m )}\end{array}$ & $\begin{array}{l}\text { Total } \\
\text { length } \\
(\mathbf{k m})\end{array}$ & $\begin{array}{l}\text { Start } \\
\text { point }\end{array}$ \\
\hline $\begin{array}{l}\text { Water } \\
\text { Course1 }\end{array}$ & 21.725 & 31.386 & 362.345 & 415.454 & $\begin{array}{l}\text { White } \\
\text { Nile }\end{array}$ \\
\hline $\begin{array}{l}\text { Water } \\
\text { Course2 }\end{array}$ & 98.368 & 28.716 & 200.201 & 327.285 & Nile \\
\hline
\end{tabular}

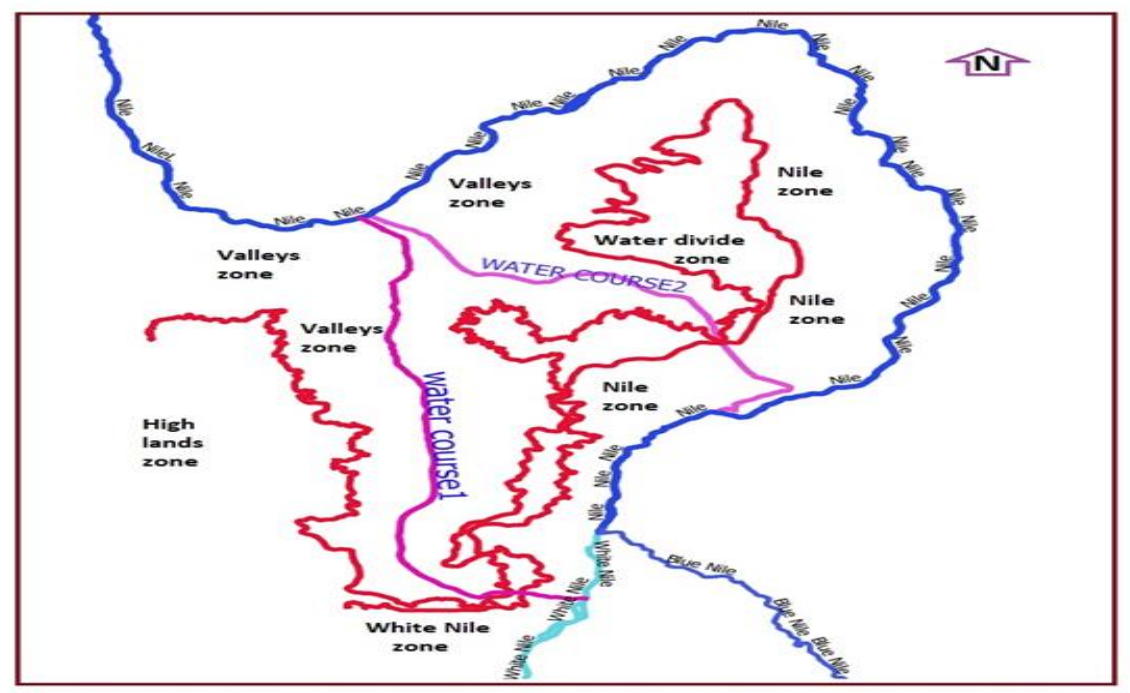

Figure 6, The locations of the proposed water courses, water course 1 and water course 2 . 
The profiles of water course 1 and water course 2 are presented in figures 7 and 8 respectively.

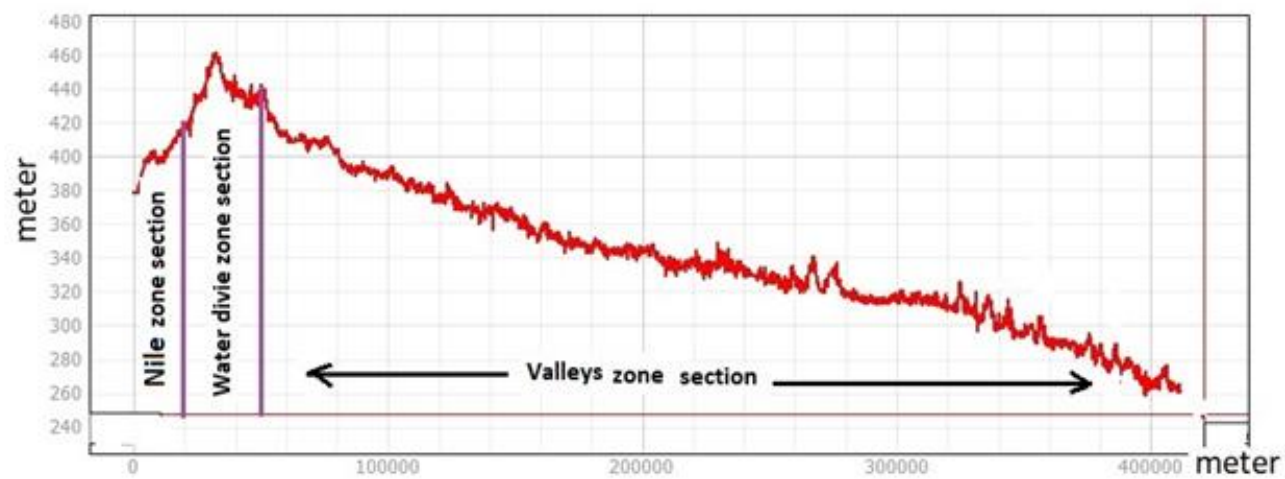

Figure 7, Profile of water course 1.

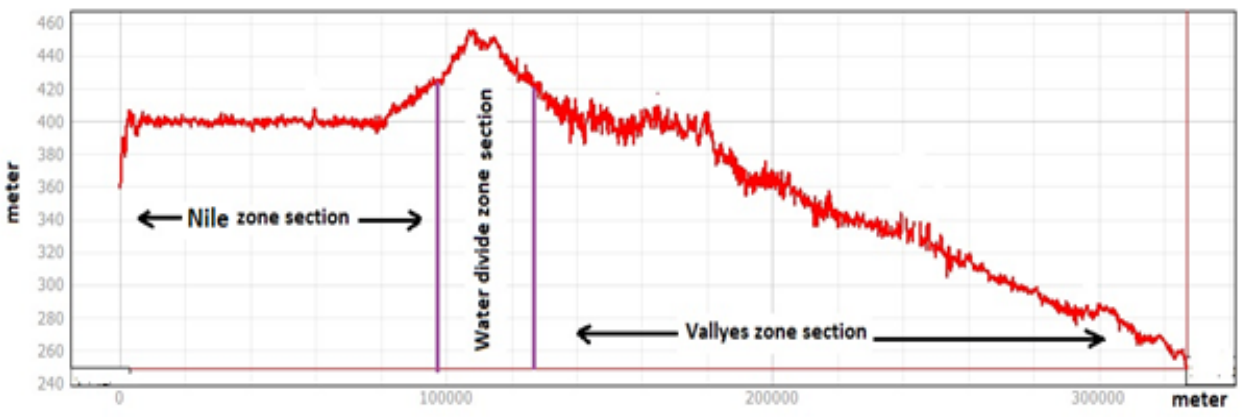

Figure 8, Profile of water course 2.

\section{Discussions}

The topographical model of the study area clearly demonstrated that to convey the water from the rivers, the route should pass though the Nile/White Nile zone and the water divide zone to reach the valleys zone. The profiles for the two water courses demonstrated that there is an up-stream section for the water to pass in both zones. These sections represent the main challenges of these water courses and the most critical factors in the proposed routes and will dominate the reliability and cost of these routes. Accordingly, the cost of the proposed routes will be mainly dominant by the values of these two parameters and the lesser the value the better the cost of the route. Through the valleys zone the routes will follow the natural drainage courses, but there is no doubt that the shorter the route the lesser the cost of construction.

The overheads for these sections are in the range of 40 to 60 meters. However, it should be mentioned that the quality of these profiles is a function of the resolution of the raw data used in the investigation and the latter was based on very course resolution data (SRTM90 data). When a detailed investigation is carried out using high resolution data (e.g. satellite images), most of the peaks in these profiles can be avoided. There is no doubt that the tradeoff will be between the length of the route and the overhead along the profile. 


\section{Conclusions}

The effort made in the investigation clearly revealed that it is quite possible to convey the water from the White Nile and the river Nile north-south section to the Nile meandering north east to south west leg via the valleys zone in the area. However, this requires the crossing of the water divide zone and the proper consideration of the upstream section between the water divide zone and the rivers. In the valleys zone the water would flow by natural gravity following the existing water courses and the only requirement is the training of the water course in certain areas. This is a great advantage as the longest section of the water course is inside the valleys zone for both water courses.

Although the investigation was carried out using course resolution data, but there is no doubt that it paved the way to a detailed investigation using high resolution data. The establishment of these water courses will no doubt improve the quality of life for the local people in the area and provide excellent chances of better life for more people to practice livestock and crop production, using pumping and flood irrigation techniques. Also, such water courses will provide good chance for the Sudanese people to better use their Nile water share, as there is a surplus of more than $4 \mathrm{bcm}$ [5] going downstream the river Nile and became a burden on and a threat to Aswan High Dam in Egypt (Sudd e Aali) [ 4], especially in the flooding seasons.

So, the conclusion is that water courses between the rivers in the study area can be created with some challenges which can be overcome. Local people standard of living can be improved and good chances for more people to settle in the area can be provided. Excellent contribution to desertification combating can be made, negative environmental impacts can be reduced by the increase of the green areas and Sudan Nile water share surplus can be reduced.

\section{Acknowledgement}

This research work is fully supported by the Deanship of Scientific Research, King Abdalaziz University.

\section{References}

[1] Shuttle Radar Topography Mission (SRTM), internet site: http://www.cgiar-csi.org/data/srtm90m-digital-elevation-database-v4-1

[2] https://download.qgis.org/

[3] https://grass.osgeo.org/documentation/first-time-users

[4] http://www.xinhuanet.com/english/2017-11/23/c_136772410.htm

[5] Salmanmasalman@gmail.com

\footnotetext{
*Corresponding author.

E-mail address: gar958gar@ gmail.com
} 